\section{Toxic effects of copper and cadmium on fertilization potency of gametes of Pacific oyster (Crassostrea gigas)}

\author{
H. Mai, B. Morin, J. Cachot \\ University of Bordeaux, Talence, France
}

\section{Introduction}

In the present study, the effects of copper (Cu) and cadmium (Cd) to the Pacific oyster Crassostrea gigas gametes were investigated. Exposure to metals concentrations of $1,5,10$, 20, $40 \mu \mathrm{g} . \mathrm{L}^{-1}$ for $\mathrm{Cu}$ and 100, 200, 400, 800, $1600 \mu \mathrm{g} . \mathrm{L}^{-1}$ for $\mathrm{Cd}$ for $30 \mathrm{~min}$ in seawater caused significant adverse effects on the fertilization success of sperm [effective concentration (EC) $50=20 \mu \mathrm{g} . \mathrm{L}^{-1}$ for $\mathrm{Cu}, \mathrm{EC} 50=830 \mu \mathrm{g} . \mathrm{L}^{-1}$ for $\mathrm{Cd}$ ] and oocytes (EC50 $=57 \mu \mathrm{g} . \mathrm{L}^{-1}$ and 1350 $\mu \mathrm{g} . \mathrm{L}^{-1}$, respectively). Lowest observed effect concentrations (LOEC) for spermiotoxicity assay were $1 \mu \mathrm{g} . \mathrm{L}^{-1}$ for $\mathrm{Cu}$ and $100 \mu \mathrm{g} . \mathrm{L}^{-1}$ for Cd. However, LOEC values for fertilization success of Cu-exposed and Cd-exposed oocytes were obtained at higher concentrations: 10 $\mu \mathrm{g} . \mathrm{L}^{-1}$ and $400 \mu \mathrm{g} . \mathrm{L}^{-1}$ for $\mathrm{Cu}$ and $\mathrm{Cd}$ respectively. It can therefore be concluded that $\mathrm{Cu}$ was more toxic than $\mathrm{Cd}$ to oyster $C$. gigas gametes where spermatids were seemingly more sensitive than oocytes. The study showed that these metals could adversely affect reproduction at environmentally realistic concentrations.

\section{Background}

Heavy metals have long been recognized as hazardous pollutants for aquatic organisms in particular at an early developmental stage. Copper $(\mathrm{Cu})$ and cadmium (Cd) are among the most dangerous metals for bivalve, ${ }^{1,2}$ shrimp $^{3}$ and sea urchin larvae. ${ }^{4}$ Although $\mathrm{Cu}$ is an essential micronutrient for aquatic animals, it can be toxic to marine organisms at elevated concentrations. Background $\mathrm{Cu}$ levels in surface water are usually low (0.03-0.23 $\mu$ g. $\left.\mathrm{L}^{-1}\right)$, but can exceed $100 \mu \mathrm{g} . \mathrm{L}^{-1}$ in severely polluted coastal areas. ${ }^{5}$ Solomon ${ }^{6}$ reported that when parental sea scallops were exposed to environmentally realistic concentrations of $\mathrm{Cu}$ at 10 $20 \mu \mathrm{g} . \mathrm{L}^{-1}$, sperm and oocyte production was decreased. In contrast to $\mathrm{Cu}, \mathrm{Cd}$ is a nonessential element which can accumulate in polluted environments reaching $\mu \mathrm{g} / \mathrm{L} .{ }^{7} \mathrm{Cd}$ has been shown to be highly toxic to bivalves embryos from Ruditapes decussatus and M. gal- loprovincialis. ${ }^{8}$ Bioassays play a crucial role in assessing the hazard of pollutants in marine organisms. Pacific oysters, particularly in their highly sensitive early life stages, are commonly used to assess the toxicity of a large variety of pollutants. ${ }^{1,9,10}$ However, previous studies on heavy metal embryotoxicity in the Pacific oyster have been mainly focused on the effect of metals on embryogenesis (from fertilization to D-shape larvae) with only limited information available on $\mathrm{Cu}$ or $\mathrm{Cd}$ toxicity to sperm and oocytes fertilizing capabilities. In the present paper, we studied the fertilizing potency of spermotozoa and oocytes of $C$. gigas exposed to $\mathrm{Cu}$ and $\mathrm{Cd}$. Our aims were to establish a doseresponse relationship for each tested metal and to assess the pollutant sensitivity of both gamete types in comparison to embryos.

\section{Materials and Methods}

Analytical grade of copper sulfate, cadmium chloride and formalin solution were purchased from Sigma-Aldrich Chemical (St. Quentin Fallavier, France). Seawater was collected from Arcachon Bay (SW of France), an area where oysters reproduce naturally. Immediately after sampling, seawater was filtered using $0.2 \mu \mathrm{m}$ pore membrane filter. Filtered seawater (FSW) was stocked at $4^{\circ} \mathrm{C}$ in the dark and was used within 3 days. Mature oysters (Crassostrea gigas) came from a commercial hatchery specialized in the year-round production of mature oysters (Guernsey Sea Farms, UK). All oysters were used within 3 days.

Stock solutions of metals $\left(500 \mathrm{mg} . \mathrm{L}^{-1}\right.$ for $\mathrm{Cd}$ and $250 \mathrm{mg} . \mathrm{L}^{-1}$ for $\mathrm{Cu}$ ) were prepared in Milli$Q$ water. Test concentrations of either metal were prepared by diluting the stock solution in FSW. The test concentrations were 1, 5, 10,20, $40 \mu \mathrm{g} . \mathrm{L}^{-1}$ for $\mathrm{Cu}$ and 100, 200, 400, 800, 1600 $\mu \mathrm{g} . \mathrm{L}^{-1}$ for $\mathrm{Cd}$. In each experiment, FSW was used as negative control. All glasswares were acid-washed before the experiments. Experimental solutions were acidified with $1 \%$ final $\mathrm{v} / \mathrm{v} 65 \%$ nitric acid and were then analyzed for $\mathrm{Cd}$ or $\mathrm{Cu}$ content by ICP-AES (Varian Vista ProAxial, Agilent Technologies, USA) using standard conditions (Table 1). Detection limits were $1 \mu \mathrm{g} . \mathrm{L}^{-1}$ for water samples.

The spermiotoxicity and oocyte toxicity tests have been described in details previously. ${ }^{10}$ Briefly, sperms cells and oocytes were exposed to metals for 30-min before they were used for fertilization. Two fertilization assays were then conducted. For Assay (1), $1.0 \mathrm{~mL}$ of exposed sperm solution was added to $10 \mathrm{~mL}$ of FSW containing unexposed oocytes. For Assay (2) $1.0 \mathrm{~mL}$ of unexposed sperm solution was added to $10 \mathrm{~mL}$ of FSW containing exposed oocytes. Embryos were incubated at $24^{\circ} \mathrm{C}$ for $2 \mathrm{~h}$ until the $2-4$ cell-stage was attained in the con-
Correspondence: Bénédicte Morin, University of Bordeaux, EPOC UMR 5805, F-33400 Talence, France.

Tel. +33.540 .0022 .56 - Fax: +33.540 .008 .719 .

E-mail: b.morin@epoc.u-bordeaux1.fr

Key words: metals, spermatids, oocytes, fertilization success, Pacific oyster.

Conference presentation: part of this paper was presented at the ECOBIM meeting, 2013 May, Montréal, Quebec, Canada.

Acknowledgements: the authors would like to thank the French and Vietnamese Governments for PhD fellowship.

This work is licensed under a Creative Commons Attribution NonCommercial 3.0 License (CC BYNC 3.0).

(C) Copyright H. Mai et al., 2013

Licensee PAGEPress, Italy

Journal of Xenobiotics 2013; 3(s1):e9

doi:10.4081/xeno.2013.sl.e9

trol treatment. To calculate the fertilization rate (FR), unfertilized oocytes were scored under an inverted microscope (Olympus, magnification x 200) among 100 oocytes.

Data are expressed as means \pm SEM (standard error mean). Differences in fertilization success were assessed for significance by oneway analysis of variance and Tukey post hoc test. The EC50 defined here as the toxicant concentrations causing $50 \%$ unsuccessful fertilization or abnormal larval development were calculated by PRISM 5 software (GraphPad Software, CA, USA).

\section{Results and Discussion}

Nominal and measured concentrations of $\mathrm{Cu}$ and $\mathrm{Cd}$ for the different applied treatments were determined (Table 1). Measured concentrations were within $10-23 \%$ of the nominal concentrations. Therefore, nominal concentrations were used for presentation and calculation of toxicity parameters. The background level of unfertilized eggs in the various controls was low as well as the response variability between replicates (ca 7\%). A significant decrease of the fertilization rate was observed after sperm exposure (Assay 1) to the lowest $\mathrm{Cu}$ and $\mathrm{Cd}$ concentrations tested $\left(1 \mu \mathrm{g} . \mathrm{L}^{-1}\right.$ and $100 \mu \mathrm{g} . \mathrm{L}^{-1}$, respectively) as compared to the control $(\mathrm{P}<0.05)$ (Figure 1). The fertilization success was reduced to $20 \%$ at the highest concentration tested for both $\mathrm{Cu}$ and $\mathrm{Cd}$. Calculated $\mathrm{EC}_{50}$ were $20 \mu \mathrm{g} . \mathrm{L}^{-1}$ for $\mathrm{Cu}$ and 827 $\mu \mathrm{g} . \mathrm{L}^{-1}$ for $\mathrm{Cd}$ (Table 2). The non-observed effect concentrations (NOECs) for $\mathrm{Cu}$ and $\mathrm{Cd}$ 
in this assay was below 1 and $100 \mu \mathrm{g} . \mathrm{L}^{-1}$ respectively. For oocyte exposure (Assay 2), $\mathrm{Cu}$ inhibited fertilization from $10 \mu \mathrm{g} . \mathrm{L}^{-1}$ concentration and $\mathrm{Cd}$ impaired fertilization at concentration of $400 \mu \mathrm{g} . \mathrm{L}^{-1}$ (Figure 1). The $\mathrm{EC}_{50}$ and NOEC data for fertilization rate are summarized in Table 2.

To date, most bioassays using bivalves have been performed using either embryos and larvae or adults, while the sensitivity of spermatozoa and oocytes to toxicants are less understood. Most of the existing data on the effects of metals on sperm and eggs have been obtained with the sea-urchin ${ }^{11,12}$ and to a lesser extend with blue mussel. ${ }^{13}$

Herein it is shown that $\mathrm{Cu}$ and $\mathrm{Cd}$ can induce deleterious effects in $C$. gigas gametes. $\mathrm{Cu}$ pre-exposure did significantly decrease fertilization capacity of oyster spermatozoa at very low concentrations $\left(1 \mu \mathrm{g} . \mathrm{L}^{-1}\right)$ consistent with those measured in harbor environment. Sperm cells of Pacific oyster seem to be more sensitive to $\mathrm{Cu}$ than spermatozoa from other marine invertebrates such as blue musse ${ }^{13}$ and sea squirt ${ }^{14}$ with LOEC at $100 \mu \mathrm{g} . \mathrm{L}^{-1}$ and $1,024 \mu \mathrm{g} . \mathrm{L}^{-1}$, respectively. In the present study, the deduced $\mathrm{EC}_{50}$ of $\mathrm{Cu}$ for oyster sperm is 20 $\mu \mathrm{g} . \mathrm{L}^{-1}$. This $\mathrm{EC}_{50}$ value is very close to that reported for spermatozoa of various sea urchins. ${ }^{15}$ Indeed, they reported an $\mathrm{EC}_{50}$ values of $25 \mu \mathrm{g} . \mathrm{L}^{-1} \mathrm{Cu}$ for purple sea urchin and 59 $\mu \mathrm{g} . \mathrm{L}^{-1} \mathrm{Cu}$ for green sea urchin. Cd was less toxic to Pacific oyster sperm cells than $\mathrm{Cu}$ with significant adverse effects observed after 30 min Cd exposure at $100 \mu g . \mathrm{L}^{-1} \mathrm{Cd}$. The $\mathrm{Cd}$ concentration causing 50\% unsuccessful fertilization on spermatozoa was $830 \mu \mathrm{g} . \mathrm{L}^{-1}$ in this study (Table 2), whereas $\mathrm{EC}_{50}$ values for several sea urchin species ${ }^{15}$ ranged from 8000 to
A

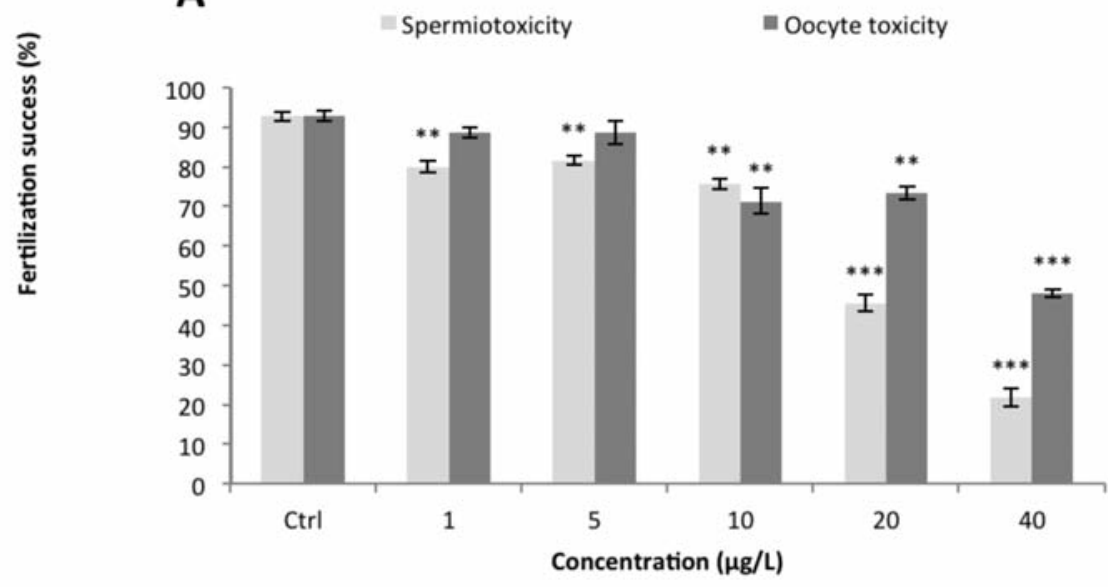

B

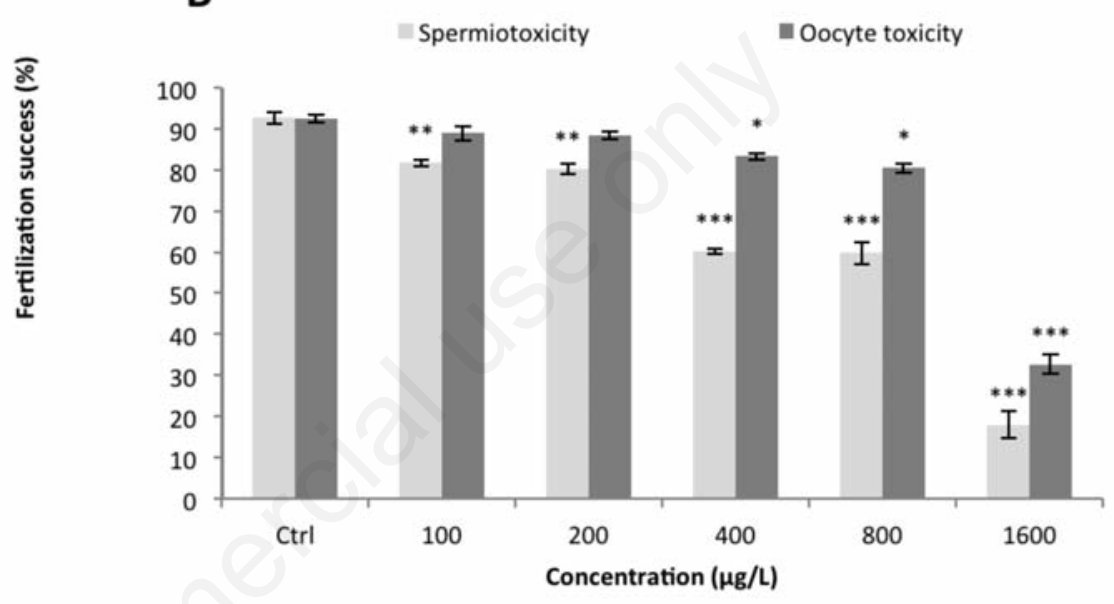

Figure 1. Percentages (mean \pm SEM) of fertilization success after gamete exposure to $(A)$ copper or $(B)$ cadmium for $30 \mathrm{~min}$. Asterisks indicate statistical differences between control and exposed treatments at ${ }^{*} \mathrm{P}<0.05,{ }^{* *} \mathrm{P}<0.01,{ }^{* * *} \mathrm{P}<0.001$.

Table 1. Copper and cadmium concentrations $\left(\mu \mathrm{g} . \mathrm{L}^{-1}\right)$ determined for exposure solutions.

\begin{tabular}{lccccccccccccc} 
& \multicolumn{1}{c}{ Copper } & \multicolumn{1}{c}{ Cadmium } \\
Nominal & $0^{*}$ & 1 & 5 & 10 & 20 & 40 & $0 *$ & 100 & 200 & 400 & 800 & 1600 & \\
Measured & $<1$ & 2.0 & 6.1 & 12.6 & 21.1 & 51.7 & $<1$ & 98 & 200 & 410 & 910 & 1610 \\
\hline
\end{tabular}

*Control seawater.

Table 2. Mean effective concentrations $\left(\mathrm{EC}_{50}\right)$ and their $95 \%$ coefficients of variation, and non-observed effect concentration (NOEC) values for different toxicity assays with $C$. gigas for cadmium and copper. Less than $(<)$ values are given for cases where NOEC could not be calculated.

\begin{tabular}{|c|c|c|c|c|}
\hline \multirow[t]{2}{*}{ Bioassays } & \multicolumn{2}{|c|}{ Cd (11g. $\left.L^{-1}\right)$} & \multicolumn{2}{|c|}{ Cu (1). $\left.L^{-1}\right)$} \\
\hline & $\mathrm{EC}_{50}$ & NOEC & $\mathrm{EC}_{50}$ & NOEC \\
\hline Spermiotoxicity & 827 (681-1005) & $<100$ & $20.3(17.8-23.1)$ & $<1$ \\
\hline Oocyte toxicity & $1346(1258-1440)$ & 200 & $57.1(37.1-88.0)$ & 5 \\
\hline Embryotoxicity* & $212(162-277)$ & $<100$ & $12.5(11.0-14.2)$ & $<1$ \\
\hline
\end{tabular}

$\mathrm{Cd}$, cadmium; $\mathrm{Cu}$, copper; $\mathrm{EC}_{50}$, effective concentrations; $\mathrm{NOEC}$, non-observed effect concentration. *Embryotoxicity data were previously published. ${ }^{9}$ 
26,000 $\mu \mathrm{g} . \mathrm{L}^{-1}$. Unlike spermiotoxicity, eggs fertilization was only altered after exposure to high exposure concentrations: $10 \mu \mathrm{g} . \mathrm{L}^{-1}$ for $\mathrm{Cu}$ and $400 \mu \mathrm{g} . \mathrm{L}^{-1}$ for $\mathrm{Cd}$. This is consistent with previous studies in which acute exposure of oocytes had no, or limited, effect on fertility. ${ }^{10,13,14} \mathrm{~A}$ likely explanation is that the complex envelop of oocyte may act as a protective barrier against metals or other contaminants accumulation into eggs. ${ }^{14}$ As previously reported, ${ }^{9}$ Pacific oyster embryos are also very sensitive to $\mathrm{Cu}$ and $\mathrm{Cd}$ inducing embryotoxicity at 0.1 $\mu \mathrm{g} . \mathrm{L}^{-1}$ for $\mathrm{Cu}$ and $10 \mu \mathrm{g} . \mathrm{L}^{-1}$ for $\mathrm{Cd}$. The $\mathrm{EC}_{50}$ values for embryotoxicity reached $12 \mu \mathrm{g} . \mathrm{L}^{-1}$ for $\mathrm{Cu}$ and $210 \mu \mathrm{g} . \mathrm{L}^{-1}$ for $\mathrm{Cd}$ (Table 2). The results are in good agreement with existing data on $\mathrm{EC}_{50}$ values of embryotoxicity assays of those metals in other marine invertebrate species.,15 The results confirm previous studies ${ }^{11}$ demonstrating that Pacific oyster embryos were more sensitive than sperm or oocytes to pollutant exposure. Gametes and embryos were relatively resistant to $\mathrm{Cd}$ toxicity compare to $\mathrm{Cu}$. The impact of Cd has apparently no ecological relevance as the effects on oyster early life stage only appear at environmentally unrealistic concentrations. We can, however, expect that $\mathrm{Cu}$ could represent a threat for the reproduction of wild or cultivated Pacific oysters in particular in the Arcachon Bay where concentrations exceeding $0.7 \mu \mathrm{g} \mathrm{L}^{-1}$ are currently measured. ${ }^{16}$

\section{References}

1. His E, Beiras R, Seaman MNL, Southward PAT, Young CM. The assessment of marine pollution-bioassays with bivalve embryos and larvae. Adv Mar Biol 1999;37:1-178.
2. Nadella SR, Fitzpatrick JL, Franklin N, Bucking C, Smith S, Wood CM. Toxicity of dissolved $\mathrm{Cu}, \mathrm{Zn}$, Ni and $\mathrm{Cd}$ to developing embryos of the blue mussel (Mytilus trossolus) and the protective effect of dissolved organic carbon. Comp Biochem Physiol C 2009;149:340-8.

3. Bambang Y, Charmantier G, Thuet P, Trilles JP. Effect of cadmium on survival and osmoregulation of various developmental stages of the shrimp Penaeus japonicus (Crustacea: Decapoda). Mar Biol 1995;123:443-50.

4. Larrain A, Riveros A, Silva J, Bay-Schmith E. Toxicity of metals and pesticides using the sperm cell bioassay with the Sea Urchin Arbacia spatuligera. Bull Environ Contam Toxicol 1999;62:749-57.

5. Bowen HJM. The cycles of copper, silver and gold. In: Hutzinger 0, ed. The handbook of environmental chemistry, The Natural Environment and the Biogeochemical Cycles. Berlin: Springer-Verlag; 1985. pp 1-27.

6. Solomon F. Impacts of copper on aquatic ecosystems and human health. Environ Commun 2009;25-8.

7. Wright DA, Welbourn PM. Cadmium in the aquatic environment: a review of ecological, physiological, and toxicological effects on biota. Environ Rev 1994;2:187-214.

8. Beiras R, Albentosa M. Inhibition of embryo development of the commercial bivalves Ruditapes decussatus and Mytilus galloprovincialis by trace metals; implications for the implementation of seawater quality criteria. Aquaculture 2004;230:20513.

9. Mai H, Cachot J, Brune J, Geffard O, Belles A, Budzinski $\mathrm{H}$, et al. Embryotoxic and genotoxic effects of heavy metals and pesticides on early life stages of Pacific oyster
(Crassostrea gigas). Mar Pollut Bull 2012;64:2663-70.

10. Mai H, Budzinski H, Pardon P, Gonzalez P, Morin B, Cachot J. Environmental concentrations of irgarol, diuron and S-metolachlor induce deleterious effects on gametes and embryos of the Pacific oyster, Crassostrea gigas. Mar Environ Res 2013; 89:1-8.

11. Warnau M, Temara A, Jangoux M, Dubois P, Iaccarino M, De Biase A, et al. Spermiotoxicity and embryotoxicity of heavy metals in the echinoid Paracentrotus lividus. Environ Toxicol Chem 1996; 15:1931-6.

12. Moschino V, Marin MG. Spermiotpxicity and embryotoxicity of triphenyltin in the sea urchin Paracentrotus lividus. Appl Organometal Chemi 2002;16:175-81.

13. Fitzpatrick JL, Nadella S, Bucking C, Balshine S, Wood CM. The relative sensitivity of sperm, eggs and embryos to copper in the blue mussel (Mytilus trossulus). Comp Biochem Physiol C 2008;147:441-9.

14. Bellas J, Vázquez E, Beiras R. Toxicity of $\mathrm{Hg}, \mathrm{Cu}, \mathrm{Cd}$, and $\mathrm{Cr}$ on early developmental stages of Ciona intestinalis (Chordata, Ascidiacea) with potential application in marine water quality assessment. Water Res 2001;35:2905-12.

15. Dinnel PA, Link JM, Stober QJ, Letourneau MW, Roberts WE. Comparative sensitivity of sea urchin sperm bioassays to metals and pesticides. Arch Environ Contam Toxicol 1989;18:748-55.

16. Geffard 0, Budzinski H, His E. The effects of elutriates from PAH and heavy metal polluted sediments on Crassostrea gigas (Thunberg) embryogenesis, larval growth and bio-accumulation by the larvae of pollutants from sedimentary origin. Ecotoxicology 2002;11:403-16. 